\section{Eotaxins may contribute to both accumulation and elimination of eosinophils in asthma}

I read with interest the study by Coleman et $a l^{1}$ on lumen eotaxins and eosinophils, and epithelial brushing eotaxins in chronic asthma. Authors conclude that eotaxin-2 and -3 may contribute to luminal migration of eosinophils. ${ }^{1}$ However, potential roles of such transepithelial cell traffic are not discussed. In a recent editorial, Rosenberg highlights the possibility that luminal migration of eosinophils importantly eliminates these cells from diseased bronchial tissues. $^{2}$ (Coleman et al ${ }^{1}$ cite an earlier review by Rosenberg et al, dealing with the complex regulation of eosinophil trafficking). A resolving role of luminal migration would complicate interpretation of eosinophil numbers recorded in sputum and broncho-alveoar lavage (BAL) fluid samples. For instance, a negative correlation between lumen and tissue eosinophils occurs at inflammation resolution. ${ }^{3}$

Involvement of eotaxin in luminal migration was implicated in the first experimental in vivo studies in guinea pigs, demonstrating efficient and non-injurious elimination of mucosal tissue eosinophils across the epithelial lining into the airway lumen (ref 3 and references cited therein). In allergen-challenged allergic mice, peak eotaxin-2 and associated eosinophilia, occurred initially in lung tissue and later in BAL fluid. ${ }^{4}$ These data agree with a role of eotaxin-2 first in early accumulation of bronchial tissue eosinophils and then in elimination of these eosinophils by luminal migration.

Coleman et al state that their data are consistent with a previous report by Ravensberg et $a l^{5}$ of 'increased eotaxin-2 and -3 in the epithelium of patients with asthma following allergen challenge'. ${ }^{1}$ Ravensberg et al actually demonstrated pronounced immunostaining of eotaxin-2 and -3 , particularly in lamina propria, and sustained eosinophilia in that location. A strong positive correlation between eotaxins $(-2$ and -3$)$ and both the subepithelial eosinophilia and the magnitude of latephase reaction was also demonstrated ${ }^{5}$ agreeing with roles of eotaxin- 2 and -3 in retaining disease-driving eosinophils in the tissue.

Three studies have recorded time course of bronchial lumen and tissue eosinophilia in allergen-challenged patients with asthma: consistently, resolution of the allergen exposure-induced asthma is associated with reduced tissue eosinophilia and increased lumen eosinophilia (references cited in ref. 3). Since apoptosis/phagocytosis of bronchial tissue eosinophils has not been compellingly demonstrated, ${ }^{2}{ }^{3}$ these data strongly support the view that luminal migration is a major mode of elimination of eosinophils from diseased asthma tissues. ${ }^{3}$ Indeed, the luminal migration mechanism may swiftly eliminate several types of cells (eosinophils, neutrophils, mast cells, lymphocytes, dendritic cells) from diseased mucosal tissues. ${ }^{3}$

\section{Carl Persson}

Department of Clinical Pharmacology, Laboratory Medicine, University Hospital Lund, Lund S22185, Sweden

Correspondence to Dr Carl Persson, Department of Clinical Pharmacology, Laboratory Medicine, University Hospital Lund, Lund S22185, Sweden; carl.persson@med.lu.se

Funding None.

Competing interests None.

Provenance and peer review Not commissioned; internally peer reviewed.

To cite Persson C. Thorax 2013;68:188-189.

Received 8 October 2012

Accepted 1 November 2012

Published Online First 26 November 2012

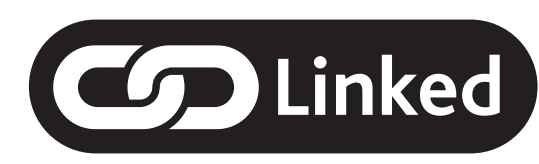

- http://dx.doi.org/10.1136/thoraxjnl-2012-202949

Thorax 2013;68:188-189.

doi:10.1136/thoraxjnl-2012-202833

\section{REFERENCES}

1 Coleman JM, Naik C, Holguin F, et al. Epithelial eotaxin-2 and eotaxin-3 expression: relation to asthma severity, luminal eosinophilia and age of onset. Thorax. 2012;67:1061-66. 
2 Rosenberg HF. Eosinophilic inflammation: life, death and apoptosis. Clin Exp Allergy 2011;41:612-14.

3 Persson C, Uller L. Transepithelial exit of leucocytes: inflicting, reflecting or resolving airway inflammation? Thorax 2010:65:1111-15.

4 Ben-Yehuda C, Bader R, Puxeddu I, et al. Airway eosinophil accumulation and eotaxin-2/CCL24 expression following allergen challenge in BALB/C mice. Exp Lung Res 2008;34:467-79.

5 Ravensberg AJ, Ricciardolo FLM, van Schadiwijk A et al. Eotaxin-2 and eotaxin-3 expression is associated with persistent eosinophilic bronchial inflammation in patients with asthma after allergen challenge.

J Allergy Clin Immunol 2005;115:779-85. 